\title{
PROPOSIÇÃO DE UMA METODOLOGIA ESTRUTURADA DE AVALIAÇÃO DO POTENCIAL REGIONAL DE REÚSO DE ÁGUA: 01 - TERMINOLOGIA E CONCEITOS DE BASE
}

\section{TOWARDS A STRUCTURED METHODOLOGY FOR ASSESSING REGIONAL WATER REUSE POTENTIAL: 01 - TERMINOLOGY AND BASIC CONCEPTS}

Ana Sílvia Pereira Santos ${ }^{a}$, Maíra Araújo de Mendonça Limaa ${ }^{a}$ Luis Carlos Soares da Silva Juniorb, Pablo da Silva Avelarc, Bruna Magalhães de Araújod, Ricardo Franci Gonçalvese, José Manuel Pereira

Vieiraf.

\author{
aUniversidade do Estado do Rio de Janeiro, buniversidade Federal do Rio de Janeiro, 'Empresa Baiana de Água e \\ Saneamento, ${ }^{d}$ Instituto Mineiro de Gestão de Águas, ${ }^{e}$ Universidade Federal do Espírito Santo, ${ }^{\dagger}$ Universidade do Minho.
}

ana.pereira@ueri.br,mairalima.90@gmail.com,luis.junior@coc.ufri.br,pablo.avelar@embasa.ba.gov.br. brunamagalhaes5@gmail.com,rfg822@gmail.com,jvieira@civil.uminho.pt

Submissão: 05 de março de 2021 Aceitação: 1 de julho de 2021

\section{Resumo}

Diante do cenário de estresse hídrico já enfrentado em diferentes regiões do Brasil, a prática do reúso de água pode ser uma importante alternativa para aliviar as pressões nos mananciais, garantir água em quantidade e em qualidade para os diversos usos, reduzir conflitos pelo uso da água e contribuir para o desenvolvimento socioeconômico regional. Para que a prática seja institucionalizada e sistematizada no país, é necessário que a cultura da conservação, do uso racional e do reúso de água seja implantada em todos os níveis da sociedade, desde usuários e produtores de água, até técnicos, tomadores de decisão e gestores de recursos hídricos e saneamento, além daqueles que tomam ações conjuntas em setores como o agrícola, o industrial, o recreacional, o de energia e outros. Estudos de avaliação estratégica do potencial regional devem ser elaborados com critérios bem definidos de forma a estabelecer um planejamento adequado, com maior possibilidade de sucesso na implantação e operação de futuros empreendimentos. Neste contexto, foi elaborado um conjunto de quatro Notas Técnicas (NT), tendo como principal objetivo a proposição de uma metodologia estruturada de avaliação do potencial regional de reúso de água no Brasil. O presente documento constitui a NT01 que tem como objetivo contextualizar a temática, além de apresentar a estruturação das demais NT e os aspectos mais relevantes para o entendimento geral da prática de reúso de água. A NT02 fornece elementos essenciais para o desenvolvimento de projetos no setor saneamento. A NT03 apresenta o caminho técnico para estudos de avaliação de potencial, considerando aspectos de demanda e oferta de água de reúso. A NT04 questiona os desafios relacionados com o futuro do reúso de água e, em especial, a sua relevância para o Brasil.

Palavras-chave: reúso de água; definições; experiência prática; regulamentação; planejamento.

\section{Abstract}

Given the water scarcity scenario that Brazil already faces, in different regions, the practice of water reuse can be an important alternative to reduce stress on water supplies, ensure water in quantity and quality for diverse uses, reduce conflicts over the use of water and contribute to regional socioeconomic development. To institutionalize and systematize the practice in the country, it is necessary to implement the conservation culture, rational use, and reuse of water, at all levels of society, from users and producers of reuse water to technicians, decision makers and water resources and sanitation managers, besides those who manage agricultural, industrial, recreational and energy sectors. Strategic evaluation studies of regional potential should be prepared with well-defined criteria to establish adequate planning, with a greater possibility of success in the implementation and operation of future enterprises. In this context, a set of four Technical Notes (TN) was prepared, with the main objective of proposing a structured methodology for assessing the regional potential of water reuse in Brazil. This document constitutes TN01, which aims to contextualize the 
theme, in addition to presenting the structuring of the other TNs and the most relevant aspects for the general understanding of the water reuse practice.TN02 provides the essential elements to develop projects in the sanitation sector. TN03 presents the technical path for potential evaluation studies, considering demand and supply aspects of water reuse. TN04 questions the challenges related to the future of water reuse, and in particular, its relevance to in Brazil.

Keywords: water reuse; definitions; practice experience; regulation; planning.

\section{INTRODUÇÃO}

Segundo a Water Europe (2020), um dos grandes desafios para a retomada da economia mundial após a pandemia da COVID-19 é o desenvolvimento de uma sociedade inteligente em termos de água (Water Smart Society) com o drástico aumento do reúso, do aproveitamento e da reciclagem da água de forma a oferecê-la de maneira segura, em quantidade e qualidade suficientes para os usos pretendidos. Melo et al. (2020a) destacam a nova centralidade da água no contexto pós-pandemia e demonstram como a sociedade deve estar preparada para aumentar os índices de reúso de água de forma a fomentar o desenvolvimento socioeconômico de regiões desfavorecidas. Evidentemente, ações conjuntas relacionadas à minimização das perdas e desperdícios de água devem ser tomadas.

O Brasil possui grandes reservas hídricas, com $255 \mathrm{mil} \mathrm{m}^{3} / \mathrm{s}$ de água escoando pelo seu território (ANA, 2020b). Porém, todo esse potencial é distribuído de forma heterogênea no país, sendo que a maior disponibilidade de água se encontra na Amazônia que, por sua vez, é a região com a menor parcela da população e a menor demanda de água no país.

A crise hídrica enfrentada pela região Sudeste do Brasil nos anos 2014 e 2015 revelouse de elevada relevância para a gestão de recursos hídricos, apesar de outras regiões do país, como o Semiárido, apresentarem essa realidade ao longo de toda a sua história. Além de baixos índices pluviométricos e altos níveis de evaporação, outros fatores contribuem para a escassez hídrica de vastas regiões do país: i) baixos índices de atendimento à coleta e ao tratamento de esgotos, acarretando o lançamento in natura de águas residuárias nos corpos hídricos; ii) elevados índices de perdas de água nos sistemas de abastecimento; iii) falta de fomento à pesquisa e, consequentemente, baixo investimento no setor; iv) cultura brasileira, geralmente baseada na percepção de alta disponibilidade hídrica e consequente uso irracional de água; entre outros.

De fato, ações de combate à poluição hídrica, ao desperdício de água e às perdas excessivas nos sistemas de distribuição de água são prioritárias no conceito do uso racional de água, que caminha na mesma direção do uso de fontes de água de origem alternativa, como o reúso. Outro destaque que corrobora a instabilidade hídrica, são as alterações climáticas que são cada vez mais evidentes em todo o planeta, agravando os eventos extremos de chuva (seca e excesso).

Nesse contexto, a prática de reúso de água pode ser uma importante alternativa para aliviar as pressões nos mananciais, garantir água em quantidade e em qualidade para os diversos usos, reduzir conflitos pelo uso da água e contribuir para 0 desenvolvimento socioeconômico regional. Várias regiões do mundo, como áreas do Oriente Médio, países da África como África do Sul e Namíbia, países mediterrânicos, Austrália, Singapura, México, Chile e diversos estados dos Estados Unidos já praticam o reúso de água de forma sistematizada (ARAUJO et al., 2018; ANGELAKIS et al., 2018), inclusive para uso potável (direto e indireto). Israel merece destaque, por praticar atualmente o reúso de $87 \%$ do efluente tratado na irrigação, superando $40 \%$ da demanda de água necessária para agricultura no país (MARIN et al., 2017).

Apesar das vantagens inerentes à prática de reúso de água, para que os empreendimentos sejam responsáveis e seguros, a gestão do risco deve estar intrinsicamente relacionada aos usos, como afirmam Santos e Vieira (2020). Os riscos microbiológicos devem ser atenuados com usos adequados e com padrões de qualidade de água que relacionam 0 risco de contaminação à exposição dos envolvidos. A Organização Mundial de Saúde (OMS) publicou padrões orientativos para reúso de água na irrigação (OMS, 2006) e para reúso potável (OMS, 2017), condizentes, principalmente, com a realidade de países em desenvolvimento e que apresentam situações de estresse hídrico, favorecendo a 
definição de padrões regionais em caráter legal.

No Brasil, ainda não existe regulamentação mandatória de abrangência federal que aborde as diferentes modalidades de reúso de água e seus respectivos padrões. Entretanto, o Programa Interáguas, elaborado no âmbito do governo federal e finalizado em 2018, apesar de não possuir força legal, apresenta diretrizes e orientações para o reúso de água no Brasil, com padrões de qualidade definidos para diferentes modalidades (irrigação, urbano, industrial, ambiental e aquicultura), visando a proteção da saúde pública, a proteção ambiental e as experiências com o tratamento de efluentes para produção de água de reúso. Ressalta-se que o Programa Interáguas apresenta apenas orientações (não padrões) para a recarga de aquíferos (reúso indireto) e para o reúso potável, não sendo esta última opção contemplada em nenhum instrumento regulatório, legal ou infralegal, sobre o reúso de água existente no país (INTERÁGUAS, 2017).

Ao nível sub-federal, alguns estados brasileiros como São Paulo, Ceará, Bahia, Minas Gerais e Rio Grande do Sul, apresentam documentos reguladores com definições de padrões para a água de reúso em relação às demandas apresentadas (SANTOS et al., 2020). De acordo com estes autores, os padrões são extremamente díspares quando comparados entre si, para os mesmos tipos de uso. Entretanto, os estados mencionados apresentam em seus documentos reguladores, importantes pontos a serem destacados, tais como: i) relação entre definição de padrões de qualidade da água de reúso e risco microbiológico de contaminação; ii) identificação visual dos tanques de armazenamento e veículos de transporte associados à prática; iii) atribuições e responsabilidades de produtores, distribuidores, usuários e demais envolvidos; iv) licenciamento obrigatório ou instrumento similar para permissão da prática de reúso; v) abordagem da fertirrigação considerando a oferta não somente de água, como também de nutrientes; entre outros. Há que se ressaltar que os valores-limite para os diferentes padrões estabelecidos para cada modalidade de reúso não devem ser caracterizados como empecilho, mas sim, como incentivo à prática do reúso de água proveniente de estações de tratamento de esgotos, de maneira segura e responsável.

Apesar da incipiência legal brasileira, em termos de reúso de água, a Lei no 14.026/2020 atualizou, recentemente, 0 marco legal do saneamento básico e destacou o reúso do efluente sanitário, fomentando a prática de reutilização, prioritariamente ao seu lançamento de forma adequada no meio ambiente, entre outros aspectos (BRASIL, 2020). Dessa forma, observa-se uma mudança na postura que pode vir a ser o gatilho para uma transformação cultural no país em relação a conservação, uso racional e reúso de água.

Hespanhol (2002) apresentou um estudo relacionado ao potencial de reúso de água no Brasil, para usos agrícolas, industriais, urbanos e em recarga de aquíferos, onde destacou a importância de uma política de reúso e de um quadro regulatório bem definidos, com o estabelecimento de estruturas institucionais para a promoção, gestão e definição de critérios de avaliação econômico-financeira de programas e projetos de reúso. Entretanto, passados quase 20 anos, o cenário não sofreu grandes alterações.

Mais recentemente, algumas pesquisas práticas vêm sendo desenvolvidas no sentido de contribuir com instrumentos de gestão e governança para a institucionalização da prática de reúso de água no território nacional. Como exemplo, Melo et al. (2020b) descrevem uma metodologia de demandas e ofertas para a implantação do reúso de água na bacia hidrográfica do rio Paracatu (Minas Gerais), com o objetivo de minimizar os conflitos pelo uso da água na região; Lima et al. (2020) realizaram um levantamento do potencial de reúso para irrigação em todas as regiões hidrográficas brasileiras (RHB), registrando um alto potencial em algumas delas, como é o caso da RHB do Paraná, onde seu potencial parcialmente instalado poderia atender $40 \%$ da demanda de água para irrigação.

O conjunto das Notas Técnicas (NT), perfazendo quatro conteúdos, tem como principal objetivo a proposição de uma metodologia estruturada de avaliação do potencial regional de reúso de água no Brasil. Seu foco principal é a inserção dessa fonte alternativa na matriz hídrica regional dentro do território nacional, de forma a propiciar o avanço do planejamento dos recursos hídricos e saneamento, como também, auxiliar gestores e tomadores de decisão. A presente Nota Técnica (NT01) tem o objetivo de contextualizar a temática, além de apresentar a estruturação das demais NT e os aspectos mais relevantes para $o$ entendimento geral da prática de reúso de água. 


\section{ESTRUTURAÇÃO DAS NOTAS TÉCNICAS}

De forma a criar uma linha de raciocínio mais clara para o entendimento e melhor aproveitamento do material desenvolvido, o conteúdo completo abordado pela construção da metodologia de diagnóstico do potencial regional de reúso de água foi estruturado em quatro Notas Técnicas: NT01 - Terminologia e conceitos de base; NT02 - Planejamento técnico e estratégico; NT03 - Metodologia de potencialidades (demandas e ofertas) e análise espacial; NT04 Desafios e tendências. Na Figura 1 pode ser observado o fluxograma geral de todo o conteúdo abordado, bem como as características principais de cada Nota Técnica.

De um modo geral, a NT01 tem como objetivo apresentar aspectos gerais e o cenário nacional para os avanços regionais em relação à prática de reúso. A NT02 levanta a necessidade de planejamento estratégico para 0 desenvolvimento de projetos no setor saneamento. A NT03 aborda a metodologia propriamente dita, de forma a apresentar aspectos relevantes e específicos para a sua construção. Por fim, a NT04 apresenta e discute desafios para reflexão e vislumbre da institucionalização da prática de reúso no futuro, no âmbito do território nacional, levantando questões abordadas nas discussões mais avançadas a nível internacional.

Salienta-se ainda que as quatro Notas Técnicas perfazem um conjunto e devem ser vistas como partes de um todo. Cada região do país tem características culturais, ambientais e socioeconômicas próprias, com soluções específicas para cenários também diferentes de estresse hídrico. As regiões mais afetadas devem programar e planejar ações a mais curto prazo, enquanto regiões menos afetadas devem ponderar ações para um futuro mais realista em termos de escassez hídrica. Em qualquer dos casos, o planejamento deve levar em consideração as alterações climáticas, o crescimento populacional e o aumento do consumo per capita e a consequente demanda de água para abastecimento, produção de alimentos e de manufaturados em geral.

\section{Figura 1: Fluxograma geral e estruturação das Notas Técnicas que compõe a construção metodológica do diagnóstico de potencial regional de reúso de água}

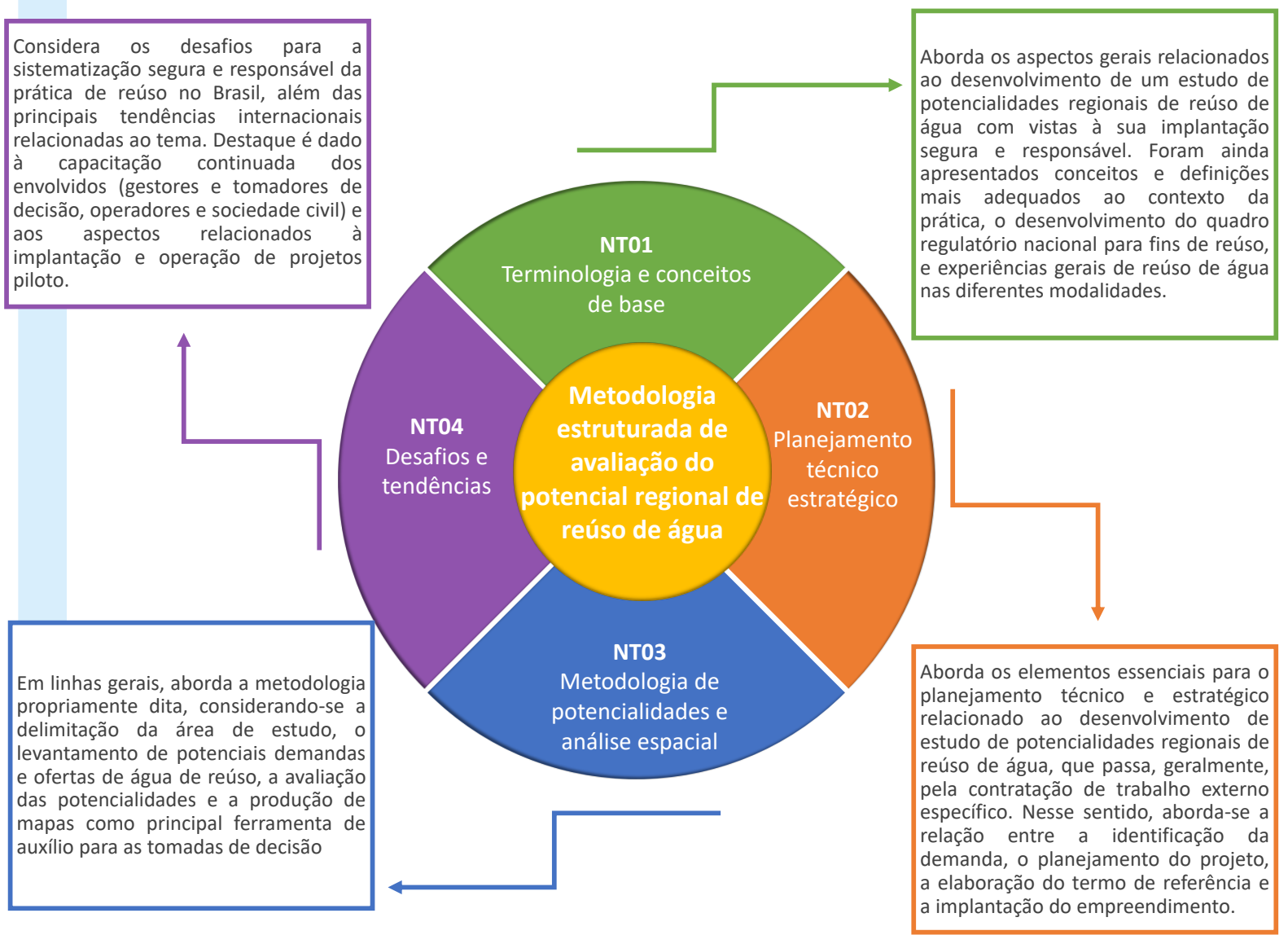

Fonte: Elaborado pelos autores. 


\section{DEFINIÇÕES}

Frequentemente, o usuário de sistemas de abastecimento de água (SAA) não conhece a procedência da água que consome, mesmo tratada para alcance dos padrões de potabilidade. Por vezes, nem sequer tem o conhecimento que o sistema de abastecimento de água que fornece água potável para seu consumo é proveniente de um reúso potável indireto não planejado. Igualmente, em geral, o consumidor de vegetais crus também não conhece a procedência da água de irrigação das culturas que consome, que segundo Bastos et al. (2002) muitas vezes pode ter qualidade inferior à do efluente tratado.

Assim, torna-se premente o entendimento sobre a necessidade de avanços no reúso de água no Brasil, acompanhando padrões e progressos estabelecidos a nível internacional. A experiência relacionada ao reúso de água no mundo é reportada desde a pré-história (ANGELAKIS et al., 2018). Em 1918, iniciou-se uma nova fase no estado da Califórnia (EUA), incorporando planejamento e regulamentação, estabelecendo-se, de maneira pioneira, padrões e diretrizes para reúso de água (ANGELAKIS et al., 2018). A partir de então, observam-se muitas experiências bem-sucedidas em todo o mundo, que devem ser levadas em consideração no desenvolvimento de uma sociedade mais receptiva e ações de governo mais direcionadas às práticas de reúso de água.

Conforme citado anteriormente, o sucesso da construção de uma real e bem-sucedida cultura de reúso de água no Brasil passa pela adoção de conceitos transparentes e corretos. Tome-se como exemplo o termo "reúso de efluente", ou mesmo "reúso de efluente tratado", muito utilizados na literatura científica atual. Tal terminologia leva à rejeição imediata da prática, motivo pelo qual se sugere o termo "reúso de água", independentemente da procedência da água. De forma complementar, no Quadro 1, observam-se conceitos importantes elaborados pelos autores com foco direto na prática do reúso de água.

\section{Quadro 1: Conceitos relacionados à prática de reúso de água}

\begin{tabular}{|c|c|}
\hline Termo & Conceito \\
\hline $\begin{array}{l}\text { Estação de } \\
\text { Tratamento de } \\
\text { Esgoto (ETE) }\end{array}$ & $\begin{array}{l}\text { A ETE é uma instalação com um conjunto de diferentes operações e processos unitários } \\
\text { para remoção de poluentes específicos presentes no esgoto. O nível de tratamento é } \\
\text { condizente com o tipo de tecnologia adotada e a qualidade do efluente desejada. O } \\
\text { tratamento a nível secundário reduz as concentrações de sólidos suspensos e } \\
\text { dissolvidos, além de matéria orgânica. No entanto, não remove eficientemente nutrientes } \\
\text { e organismos indicadores de contaminação fecal. A remoção de ambos está } \\
\text { condicionada à modalidade de reúso. }\end{array}$ \\
\hline $\begin{array}{l}\text { Estação de } \\
\text { Tratamento } \\
\text { Avançado } \\
\text { ou } \\
\text { Estação } \\
\text { Produtora de } \\
\text { Água de Reúso }\end{array}$ & $\begin{array}{l}\text { Uma "Estação de Tratamento Avançado" produz efluente tratado com qualidade superior } \\
\text { ao tratamento a nível secundário. Caso a água tratada seja destinada ao reúso, a } \\
\text { estação passa a ser considerada como uma "Estação Produtora de Água de Reúso } \\
\text { (EPAR)". Ressalta-se ainda que seu nível de tratamento é definido a partir da qualidade } \\
\text { de água almejada para o uso pré-determinado, sendo nela inseridas as tecnologias para } \\
\text { se atingir a eficiência necessária. }\end{array}$ \\
\hline Desinfecção & $\begin{array}{l}\text { A desinfecção é uma etapa do tratamento avançado e visa eliminar ou reduzir a } \\
\text { patogenicidade presente no esgoto. Seu desempenho pode ser modulado a diferentes } \\
\text { níveis de eficiência, tendo em vista os objetivos do reúso de água. A cloração, a radiação } \\
\text { UV e a ozonização são os processos mais utilizados, embora lagoas de maturação ou de } \\
\text { polimento também sejam utilizadas em casos de reúso de água na agricultura. Também } \\
\text { podem ser adotados processos em duplo estágio, considerando uma filtração terciária } \\
\text { antecedente à unidade de desinfecção, com objetivo de redução da turbidez. }\end{array}$ \\
\hline $\begin{array}{l}\text { Água de reúso ou } \\
\text { água para } \\
\text { reutilização }\end{array}$ & $\begin{array}{l}\text { Água produzida por uma EPAR com o objetivo de reinserção nos ciclos urbano ou rural } \\
\text { da água. Sua qualidade deve ser compatível com o uso e oferecer os menores riscos } \\
\text { possíveis à saúde humana e ao meio ambiente. No contexto internacional, os termos } \\
\text { mais utilizados são "água reciclada" (recycled water) e "água recuperada" (reclaimed } \\
\text { water). Conforme já mencionado, não se consideram adequados os termos "reúso de } \\
\text { efluente" ou "reúso de efluente tratado". }\end{array}$ \\
\hline Reúso de água & $\begin{array}{l}\text { Termo adotado para a utilização de águas residuárias na cidade ou no campo. Tem } \\
\text { como requisito primordial a adequação da qualidade da água ao uso almejado, sempre } \\
\text { com base na segurança sanitária e ambiental. }\end{array}$ \\
\hline
\end{tabular}


Termo

Reúso direto

Reúso indireto

Reúso interno

Reúso externo

Sistema centralizado de esgotamento sanitário

Sistema descentralizado de esgotamento sanitário

Reúso agrícola

Reúso urbano

Reúso Industrial

Reúso em piscicultura ou aquicultura

Reúso ambiental

Reúso potável

Reúso potável direto

Reúso potável indireto Reúso potável indireto não planejado ( $D e$ Facto)

\section{Conceito}

Refere-se ao uso planejado da água produzida em uma EPAR, sem que haja lançamento prévio em corpos d'água superficiais ou subterrâneos.

Refere-se ao efluente de uma EPAR utilizado para qualquer fim após lançamento em um corpo hídrico superficial ou subterrâneo.

Refere-se ao efluente tratado quando utilizado dentro das próprias instalações onde ele foi produzido, nomeadamente na própria ETE ou no mesmo estabelecimento.

Refere-se ao efluente tratado quando encaminhado para reúso em ambientes externos àquele onde ele foi produzido. Ou seja, para usuários externos.

Quando o esgoto sanitário de uma determinada bacia de esgotamento é coletado e transportado por um sistema coletivo para ser tratado em uma ETE única. Neste caso, o reúso de água pode ser do tipo interno ou externo.

Sistema que coleta e trata o esgoto sanitário produzido in loco, como condomínios residenciais e comerciais, empreendimentos empresariais e comerciais, loteamentos e edifícios singulares. Neste caso, em geral, a prática de reúso é do tipo interna, considerando inclusive a possibilidade de separação das diferentes águas provenientes de bacias sanitárias (águas negras) e dos demais acessórios hidráulicos, exceto de pia de cozinha e máquina de lavar louça (águas cinza).

Aplicação da água de reúso em irrigação de diferentes tipos de cultura e a partir de diferentes tipos de equipamentos de irrigação. Ressalta-se que os diferentes tipos de cultura requerem águas de diferentes qualidades. Em geral, nesse processo incluem-se os seguintes aspectos relacionados às culturas: i) consumo cru ou após algum tipo de processamento; ii) desenvolvimento rente ou distante do solo; iii) consumo humano ou não; iv) que apresentam contato direto com a água de irrigação ou não; e outros.

Aplicação da água de reúso em ambientes urbanos para usos como lavagem de pátios, estacionamentos, logradouros públicos e similares; irrigação paisagística de canteiros, praças e parques; lavagem de veículos comuns e especiais como trens, metrôs, aviões, ônibus e caminhões de lixo; desobstrução de galerias de águas pluviais e/ou tubulações de esgotos sanitários; diversas situações na construção civil, como cura de concreto, maquinário que utiliza água para o funcionamento, umectação de solo, abaixamento de poeira; combate a incêndio; descarga de bacia sanitária em sistemas descentralizados.

Aplicação da água de reúso em ambientes industriais: 1) aplicação no parque industrial como água de processo e/ou em equipamentos como caldeiras e torres de resfriamento; 2) aplicação do tipo urbana, porém em ambiente industrial. Nesse caso, a água de reúso para atividades industriais pode ser proveniente de um reúso interno ou externo, bem como de um sistema centralizado ou descentralizado.

Aproveitamento na criação de espécies aquáticas (aquicultura) ou especificamente de peixes (piscicultura). A água de reúso é então direcionada aos tanques de criação dessas espécies, geralmente destinadas ao consumo humano.

O reúso ambiental se caracteriza por aplicação em situações que consideram algum tipo de recuperação ambiental como a de áreas degradadas, em florestas plantadas, recarga de aquífero, aumento de vazão em lagos ornamentais, fixação de vazões ecológicas de cursos d'água e outros.

Reúso de água para fins de abastecimento humano, podendo ser dividido em reúso potável direito, reúso potável indireto e reúso potável indireto não planejado, também conhecido como reúso potável De Facto.

É a inserção da água de reúso no sistema de abastecimento de água, sem amortecimento ambiental (como diluição em águas subterrâneas ou águas superficiais) previamente à captação. Ou seja, a água de reúso é misturada diretamente à água captada do manancial (superficial ou subterrâneo) para tratamento na Estação de Tratamento de Água (ETA) ou à água potável no sistema de distribuição.

A água de reúso é diluída no manancial de captação (superficial ou subterrâneo), de forma planejada, para aumento da vazão e posterior tratamento e distribuição.

Quando a água residuária (bruta ou tratada) é lançada indiscriminadamente, sem planejamento, no corpo d'água, a montante de uma captação para abastecimento de água. 


\begin{tabular}{|c|c|}
\hline Termo & Conceito \\
\hline Reúso restrito & $\begin{array}{l}\text { Trata-se de uma classificação a partir do grau de restrição ao usuário. No reúso restrito, } \\
\text { o acesso do público à água de reúso é restringido e, portanto, há maior flexibilidade em } \\
\text { relação à qualidade exigida. }\end{array}$ \\
\hline Reúso irrestrito & $\begin{array}{l}\text { De maneira análoga, trata-se de uma classificação a partir do grau de restrição ao } \\
\text { usuário. Entretanto, no reúso irrestrito, o acesso do público à água de reúso é liberado e, } \\
\text { portanto, deve haver maiores rigor e exigência em relação à qualidade da água. }\end{array}$ \\
\hline Critérios de reúso & $\begin{array}{l}\text { Critérios desenvolvidos com base nas informações disponíveis e na opinião científica. } \\
\text { Oferecem restrições qualitativas (limites numéricos e narrativos) para a prática do reúso } \\
\text { de água e servem como base para o desenvolvimento dos padrões de qualidade. Em } \\
\text { geral, por não considerarem a viabilidade técnica e econômica, não são mandatórios. }\end{array}$ \\
\hline $\begin{array}{l}\text { Padrões de } \\
\text { qualidade de água } \\
\text { de reúso }\end{array}$ & $\begin{array}{l}\text { Restrições qualitativas, com limites numéricos, estabelecidas como regra, princípio ou } \\
\text { medida, pela autoridade competente. São valores atribuídos a parâmetros de qualidade } \\
\text { de água que se configuram como limites para o reúso de água em diferentes } \\
\text { modalidades. }\end{array}$ \\
\hline $\begin{array}{l}\text { Diretrizes de } \\
\text { reúso }\end{array}$ & $\begin{array}{l}\text { Orientações, normalmente voluntárias, consultivas e não obrigatórias. Servem como } \\
\text { base para o desenvolvimento de um instrumento legal mandatório e envolvem critérios e } \\
\text { padrões de qualidade. }\end{array}$ \\
\hline $\begin{array}{l}\text { Regulamento de } \\
\text { reúso }\end{array}$ & $\begin{array}{l}\text { Documento com padrões, critérios ou diretrizes adotados oficialmente pelo órgão } \\
\text { competente regional (municipal, estadual, federal). }\end{array}$ \\
\hline $\begin{array}{l}\text { Avaliação de risco } \\
\text { microbiológico }\end{array}$ & $\begin{array}{l}\text { O reúso de água traz uma característica inerente à sua prática que é o risco } \\
\text { microbiológico de contaminação (de seres humanos e meio ambiente), ao se tratar da } \\
\text { reinserção de um efluente no meio, mesmo que tratado, para diferentes usos. Dessa } \\
\text { forma, a avaliação (quantitativa, semiquantitativa ou qualitativa) de risco microbiológico } \\
\text { estima os possíveis riscos associados à prática de reúso, com o objetivo de reduzi-los } \\
\text { até um nível mínimo considerado aceitável. }\end{array}$ \\
\hline Barreiras & $\begin{array}{l}\text { Obstáculos físicos ou químicos que se interpõem à transmissão de perigos e são } \\
\text { responsáveis pela redução do contato do receptor (usuário, operador ou demais } \\
\text { envolvidos) com a água de reúso. As barreiras podem atuar individualmente ou em } \\
\text { conjunto (multibarreiras). }\end{array}$ \\
\hline $\begin{array}{l}\text { Plano de gestão } \\
\text { de riscos }\end{array}$ & $\begin{array}{l}\text { O plano de gestão de riscos é elaborado tendo em consideração a probabilidade de } \\
\text { ocorrência de todos os perigos (físicos, químicos e microbiológicos), associada à } \\
\text { severidade das suas consequências, e a eficácia das barreiras instaladas e a instalar em } \\
\text { todas as operações associadas ao reúso. }\end{array}$ \\
\hline $\begin{array}{l}\text { Produtor e/ou } \\
\text { distribuidor de } \\
\text { água de reúso }\end{array}$ & $\begin{array}{l}\text { Pessoa física ou jurídica responsável pela produção e/ou distribuição da água de reúso } \\
\text { em quantidade e qualidade firmadas em contrato e compatíveis com os tipos de reúso } \\
\text { acordados. }\end{array}$ \\
\hline $\begin{array}{l}\text { Consumidor da } \\
\text { água de reúso }\end{array}$ & $\begin{array}{l}\text { Pessoa física ou jurídica responsável por receber a água de reúso de acordo com as } \\
\text { características firmadas em contrato e usá-la nas condições e nas modalidades } \\
\text { especificadas no mesmo documento. }\end{array}$ \\
\hline $\begin{array}{l}\text { Licenciamento } \\
\text { e/ou autorização }\end{array}$ & $\begin{array}{l}\text { Instrumentos legais, emitidos pelos órgãos competentes, onde são estabelecidas as } \\
\text { condições de autorização da prática de reúso. }\end{array}$ \\
\hline
\end{tabular}

\section{EVOLUÇÃO DA REGULAMENTAÇÃO DA PRÁTICA DE REÚSO DE ÁGUA NO BRASIL}

Até ao presente momento, o Brasil não dispõe de um instrumento legal a nível federal que regulamente o reúso de água em seu território. O histórico de desenvolvimento de um quadro regulatório da prática de reúso no país se iniciou com a publicação de padrões não mandatórios em 1997, seguindo-se a publicação de regulamentos sub-federais no ano de 2020 (Figura 2). Nessa linha do tempo, com duração de mais de 20 anos, há a publicação de critérios, diretrizes e regulamentos para fins de reúso, com e sem a definição de padrões.

A primeira publicação sobre a temática de reúso de água proveniente de estações de tratamento de esgotos, no Brasil, foi a NBR 13.969:1997, intitulada "Tanques sépticos Unidades de tratamento complementar e disposição final dos efluentes líquidos - Projeto, construção e operação". Esta Norma Brasileira, publicada pela Associação Brasileira de Normas Técnicas em 1997, apesar de não ser mandatória, possui um caráter regulador, demonstrando, já à data, preocupação e interesse no reúso de água a partir do esgoto tratado, como alternativa para minimização das pressões sobre 
os recursos hídricos. Observa-se pelo seu título que a abordagem do reúso contemplando a utilização local para diversas finalidades, excluindo o consumo humano, está inserida no contexto localizado, caracterizando atualmente um sistema descentralizado, justificado pelo título do seu item 5.6: "reúso local". De maneira geral, deve ser dado destaque à abordagem de planejamento do empreendimento de reúso na norma, que há mais de 20 anos já indicava a necessidade de previsão dos usos, de estimativa do volume a ser utilizado, de definição do grau de tratamento necessário para o atendimento à qualidade desejada, de previsão de sistema de reservação e distribuição, além da sugestão de elaboração de um manual de operação e treinamento dos responsáveis (ABNT, 1997).

As modalidades de reúso abordadas na NBR 13.969:1997 são categorizadas em 4 classes. Cada classe, relaciona o tipo de uso da água ao grau de tratamento necessário para alcance da qualidade definida em padrões. Nela, foram previstos os seguintes usos, do mais restritivo para o menos restritivo: lavagem de carros, pisos, calçadas; irrigação de jardins; descargas de bacias sanitárias; aplicação em pomares, cerealíferas, forrageiras, pastagens para gados, entre outros.

Atualmente, a NBR 13.969:1997 encontra-se desatualizada apesar da sua grande relevância para a inserção da discussão sobre o reúso de água no cenário nacional, no final dos anos 90 . Essa desatualização pode ser observada através dos níveis extremamente avançados de tratamento de esgoto localizado, como por exemplo o fluxograma composto por tratamento aeróbio, seguido de filtração convencional e cloração, ou até mesmo com a substituição da filtração convencional por tecnologia de membranas, naquela época chamadas de membranas filtrantes. Na prática, atualmente, a grande maioria das ETEs descentralizadas no país é composta por sistemas simplificados de fossa séptica ou fossa séptica seguida de filtro anaeróbio. No contexto dos sistemas centralizados, atualmente, somente $7 \%$ de todo o esgoto tratado no Brasil passa por algum tipo de desinfecção (em sua maioria lagoas de maturação) (LIMA et al., 2020) e, de acordo com ANA (2020a), somente 18 das 3.668 ETEs em operação no país possuem membranas em seus fluxogramas de tratamento).

Somente em 2005 foi publicada a Resolução do Conselho Nacional de Recursos Hídricos
(CNRH) no 54, que estabeleceu modalidades, diretrizes e critérios gerais com o objetivo de regulamentar e estimular a prática de reúso direto não potável de água. O seu artigo 3ำ apresenta cinco modalidades de reúso (urbano, agrícola/florestal, ambiental, industrial e aquicultura) (BRASIL, 2005). Entretanto, esta Resolução não define padrões de qualidade de água de reúso e passa essa atribuição aos órgãos ambientais. Dessa forma, no ano de 2005 o país perdeu uma importante oportunidade de estabelecer critérios e objetivos específicos de reúso de água de forma a fomentar o seu desenvolvimento. Em 2011, o Conselho Nacional de Meio Ambiente (CONAMA) publicou a Resolução no $\mathbf{4 3 0}$, que estabelece condições e padrões de lançamento de efluentes (BRASIL, 2011). De fato, essa Resolução não tem o objetivo de estabelecer critérios de reúso. Porém, como a reutilização de efluentes pode ser entendida como uma forma de disposição final adequada, assim como o lançamento em corpos d'água, a resolução poderia ter realçado essa questão. No entanto, somente afirma que as fontes potencial ou efetivamente poluidoras devem proceder ao reúso sempre que possível e adequado, visando o uso eficiente da água. Novamente, com a publicação deste documento em 2011 o Brasil também perdeu a oportunidade de avançar em termos de regulamentação do reúso de água.

Nessa linha do tempo, o Programa de Pesquisa em Saneamento Básico (PROSAB), financiado pelo governo federal, desenvolveu importantes pesquisas e produziu relevantes resultados para 0 desenvolvimento do saneamento básico no Brasil entre o final da década de 1990 e o início dos anos 2000. Conforme compilado por Bastos et al. (2008), o PROSAB propôs padrões de reúso de água para agricultura, piscicultura e ambientes urbanos, alinhados à avaliação de risco microbiológico e às características ambientais, culturais e socioeconômicas brasileiras. Entretanto, por se tratar apenas de diretrizes, os critérios e padrões são meramente orientativos e sua adoção é voluntária e não mandatória. Destaca-se ainda que os padrões do PROSAB foram definidos com base na metodologia de AQRM (Avaliação quantitativa de risco microbiológico) recomendada pela OMS, o que os torna mais flexíveis e adaptáveis à capacidade de investimento e ao desenvolvimento tecnológico nacional (SANTOS et al., 2020). 
Figura 2: Linha do tempo do estabelecimento do quadro regulatório (mandatório e não mandatório) de reúso de água no Brasil

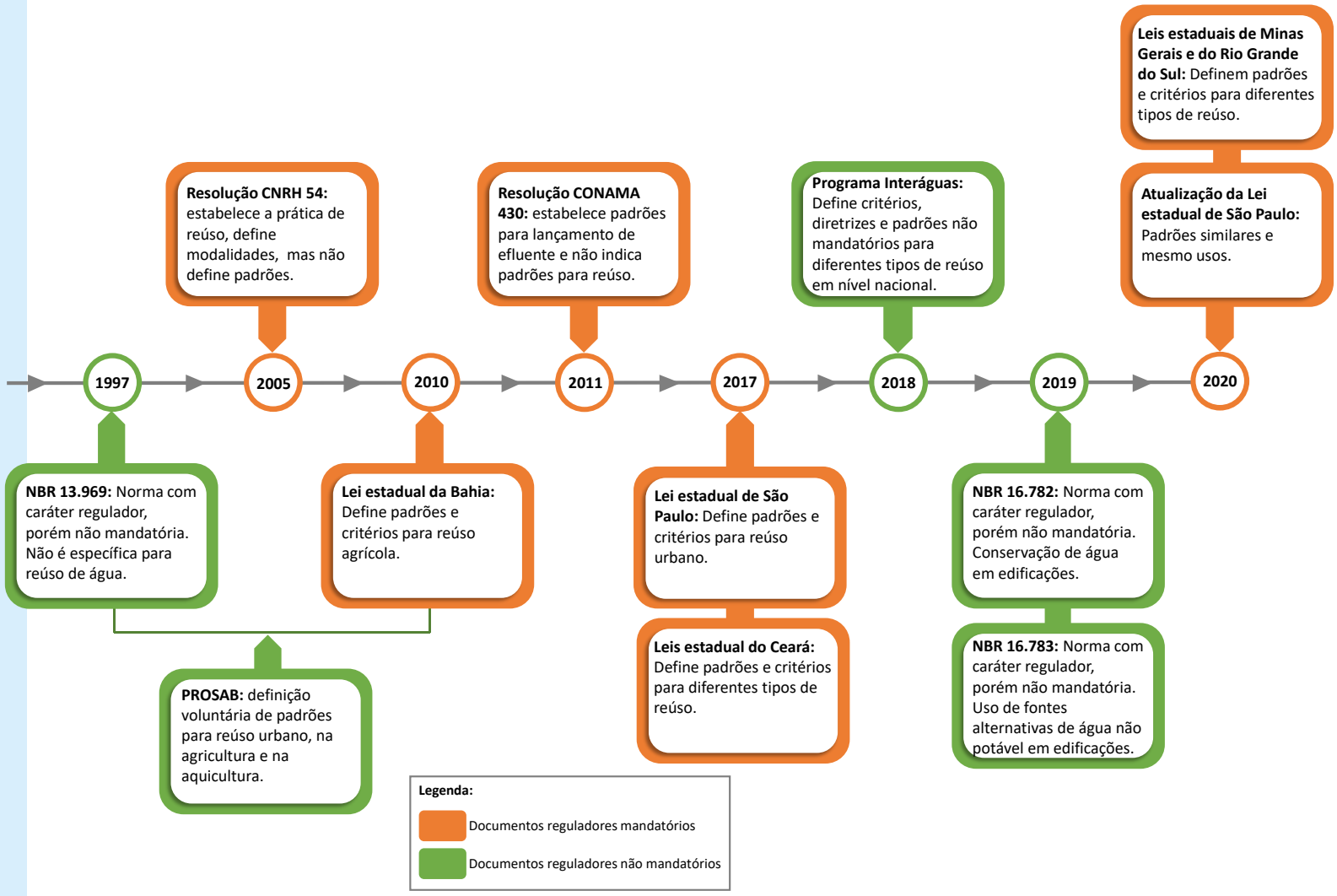

Fonte: Elaborado pelos autores.

Links disponíveis para consulta dos documentos reguladores abordados na Figura 2: Bahia - Resolução do Conselho Estadual de Recursos Hídrico no 75/2010; Ceará - Resolução COEMA n 2/2017; Programa Interáguas (2017); São Paulo - Resolução conjunta SES/SIMA n 1/2020; Rio Grande do Sul - Resolução do Conselho Estadual do Meio Ambiente no 419/2020; Minas Gerais - Deliberação Normativa do Conselho Estadual de Recursos Hídrico n65/2020; Bastos et al. (2008); Conselho Nacional de Recursos Hídricos - Resolução no 54 de 2005; Conselho Nacional do Meio Ambiente - Resolução no 430 de 2011. As NBR 13.969:1997, NBR 16.782:2019 e NBR 16.783:2019 são de acesso restrito e, portanto, não têm seus links de acesso disponibilizados aqui.

No nível sub federal, a primeira legislação brasileira com a indicações de padrões para 0 reúso de água ocorreu no ano de 2010, no estado da Bahia, que estabeleceu procedimentos para a prática na modalidade agrícola e/ou florestal, baseada nas diretrizes da OMS, de 2006. No ano de 2017, o estado do Ceará apresentou, em sua regulamentação para lançamento de efluentes líquidos, diretrizes, critérios e parâmetros para 0 reúso não potável de água em diversas modalidades. Nesse mesmo ano, o estado de São Paulo definiu critérios e padrões mandatórios para o reúso urbano de água a partir de efluentes de estações de tratamento de esgotos. Já no ano de 2020, dois estados (Minas Gerais e Rio Grande do Sul) publicaram legislações referentes à prática, com a definição de padrões para as modalidades pré-definidas nos documentos; e o estado de São Paulo atualizou a sua lei para o mesmo fim.

Em 2019, com o objetivo de orientar a conservação e o uso da água em edificações, a Associação Brasileira de Normas Técnicas publicou a NBR 16.782:2019 (sobre requisitos, procedimentos e diretrizes para a conservação de água em edificações) (ABNT, 2019a) e a NBR 16:783:2019 (sobre o uso de fontes alternativas de água não potável em edificações) (ABNT, 2019b). Juntas, elas representam importante papel para a consolidação da prática de reúso de água em sistema descentralizado de esgotamento sanitário, ao nível nacional, apesar de não apresentarem obrigatoriedade.

Ao nível federal, somente em 2017 os padrões de reúso de água foram definidos em diretrizes orientativas e não mandatórias, publicadas pelo Programa Interáguas, financiado pelo governo federal. O documento 
apresentou padrões para as modalidades de irrigação, urbano, industrial, ambiental e aquicultura, considerando as dimensões ambientais, econômico-financeira, social e cultural, e de saúde pública (INTERÁGUAS, 2017). Esse documento ainda define fluxogramas de tratamento de esgotos para alcance dos padrões indicados para cada modalidade, como também apresenta recomendações de licenciamento para cada tipo de reúso. Apesar de não mandatório, ele apresenta os principais padrões de qualidade de água de reúso para os diferentes tipos definidos no nível nacional (Tabela 1).

A atualização do marco regulatório do saneamento básico, Lei no 14.026 de 2020, define o estabelecimento de normas de referência para o setor, inclusive para a prática de reúso de água, como competência da Agência Nacional de Águas e Saneamento Básico (ANA).

Com uma regulamentação mais bem definida, o reúso de água pode vir a se estabelecer como mais uma ferramenta de grande eficácia no gerenciamento dos recursos hídricos e saneamento no Brasil. Nesse sentido, Santos e Vieira (2020) afirmam que a própria expriência nacional é que deve ser responsável pelo aprimoramento da prática e pela atualização de padrões cada vez mais adequados.

Tabela 1: Padrões do Programa Interáguas definidos para as diferentes modalidades de reúso

\begin{tabular}{ll}
\hline \multicolumn{1}{c}{ Padrões de reúso } & \multicolumn{1}{c}{ Observações } \\
\hline Agrícola restrito & Agrícola restrito: irrigação de cultura alimentícia que \\
Coliformes Termotolerantes: $10^{3} \mathrm{NMP} / 100$ & se desenvolve distante do solo sem processamento \\
$\mathrm{mL} ; \mathrm{DBO}: 30 \mathrm{mg} / \mathrm{L} ;$ Cloro residual: $>1,0$ & prévio; após processamento prévio; não destinadas ao \\
$\mathrm{mg} / \mathrm{L}$. & consumo humano; cultivo de florestas plantadas. \\
\hline
\end{tabular}

\section{Agrícola irrestrito}

Coliformes Termotolerantes: $10 \mathrm{NMP} / 100$ $\mathrm{mL}$; Turbidez: 5 UNT; DBO: $15 \mathrm{mg} / \mathrm{L}$; Cloro residual: > 1,0 $\mathrm{mg} / \mathrm{L}$.
Urbano restrito
Coliformes Termotolerantes: $10^{3}$ NMP/100 mL; Turbidez: 5 UNT; DBO: 30 mg/L; Cloro residual: > 1,0 $\mathrm{mg} / \mathrm{L}$.

\section{Urbano irrestrito}

Coliformes Termotolerantes: 10 NMP/100 mL; Turbidez: 5 UNT; DBO: 15 mg/L; Cloro residual: > 1,0 mg/L.

Industrial
$\mathrm{mL}$.

Ambiental
Coliformes Termotolerantes: $10^{3}$ NMP/100
$\mathrm{mL}$; DBO: $60 \mathrm{mg} / \mathrm{L}$.

\section{Aquicultura}

Coliformes Termotolerantes: $10^{3}$ NMP/100 $\mathrm{mL}$; DBO: $60 \mathrm{mg} / \mathrm{L}$.

Fonte: Interáguas (2017).

\section{EXPERIÊNCIA E POTENCIAL NACIONAIS}

O reúso de água vem sendo praticado no Brasil, porém ainda de maneira tímida e muitas vezes sem a observância de critérios. Como se analisou no item anterior, o quadro regulatório, apesar de apresentar longo desenvolvimento,
Agrícola irrestrito: irrigação de cultura alimentícia que se desenvolve rente ao solo sem processamento prévio.
Urbano restrito: irrigação paisagística e outros usos em áreas restritas, tais como desobstrução de redes de esgoto, construção civil, lavagem de veículos e combate a incêndio

Urbano irrestrito: irrigação paisagística, bacias sanitárias e lavagem de logradouros.

Industrial: Aplicação em vários processos e atividades industriais.

Ambiental: Aplicação em lagoas urbanas, manutenção de wetlands e aumento da disponibilidade hídrica para fins ambientais.

Aquicultura: criação de peixe ou cultivo de vegetais aquáticos. 
reúso de uma forma institucionalizada, em geral, não apresentam dados claros e transparentes em seus websites. Esse cenário é bem ilustrado por Silva Junior et al. (2019), que desenvolveram um estudo com o objetivo de analisar o estado da arte do reúso de água na região Sudeste do país. Os autores concluíram que, do universo de 1287 ETEs em operação na região, foram encontrados projetos de reúso somente em 16 instalações e, desse montante, apenas 10 dispunham de dados quantitativos públicos. Ressalta-se que, juntas, as ETEs destacadas têm capacidade de produção de $1158,2 \mathrm{~L} / \mathrm{s}$ de água de reúso, o que correspondente a uma população equivalente de aproximadamente 800 mil habitantes, considerando-se um consumo per capita de água médio de 120 L/hab.dia.

Araujo et al. (2017) destacam a questão relacionada ao tipo de transporte da água de reúso, que também não está bem definida no Brasil. As possibilidades de transporte por caminhão pipa ou por adução ainda são questionadas na maioria dos projetos de reúso, o que tem levado ao abandono de alguns projetos antes mesmo da sua elaboração. Neste contexto, são levantadas questões importantes relacionadas à operacionalização dos empreendimentos e ao uso de combustível fóssil para uma aplicação sustentável de água de reúso. De um lado estão os empreendimentos de grande porte, centralizados, que requerem 0 transporte da água de reúso por adução. As incertezas quanto à aplicabilidade e à continuidade do projeto frequentemente limitam a construção de um sistema de distribuição mais robusto dedicado a este fim. Por outro lado, a distribuição da água de reúso por meio de caminhões pipa, com uso de combustível fóssil, caminha exatamente no sentido oposto da sustentabilidade que está na origem do próprio reúso de água. Essas questões ainda necessitam mais atenção, por parte de gestores e tomadores de decisão, no sentido de se favorecer a institucionalização desta importante prática no país.

Mesmo diante das dificuldades discutidas, o Brasil já acumula alguma experiência em termos de reúso de água, principalmente com projetos descentralizados. Quanto aos projetos de reúso centralizados, algumas companhias de água e esgoto já vêm produzindo estudos de planejamento de potencial de reúso para os efluentes gerados nas ETEs que operam. No estado da Bahia, o Projeto contratado pela
Empresa Baiana de Águas e Saneamento (EMBASA), denominado Estudo de Avaliação de Potencialidades de Reúso de Efluente Sanitário Tratado no Estado da Bahia, teve duração de 1 ano e foi finalizado em novembro de 2020, com a indicação da ETE Vitória da Conquista para instalação de Projeto Piloto (IICA, 2020). No estado de Pernambuco, a Companhia Pernambucana de Saneamento (COMPESA) lançou edital em dezembro de 2020 para o desenvolvimento de estudo de viabilidade técnica, econômico-financeira, socioambiental e jurídica para celebração de parcerias para fins de exploração dos subprodutos, inclusive água de reúso, gerados nas ETEs operadas pela Companhia (COMPESA, 2020). Nesse contexto, destaque ainda deve ser dado à Sociedade de Abastecimento de Água e Saneamento de Campinas/SP (SANASA), que já apresenta na página principal do seu website, link para "Caminhão Pipa Água de Reúso" que define os critérios, preços e modalidades de compra da água de reúso oferecida pela companhia. (SANASA, 2020).

Em geral, os projetos já em andamento no Brasil se inserem nos contextos urbano, agrícola e industrial, em função das especificidades regionais. Entretanto, outros usos que englobam a aquicultura, a piscicultura e a recuperação ambiental também apresentam um bom potencial.

\subsection{URBANO}

O reúso de água em ambientes urbanos já vem sendo praticado nas grandes cidades do país para fins "menos nobres". No Rio de Janeiro, segundo Araujo et al. (2016), a ETE Penha, operada pela Companhia de Água e Esgotos do Rio de Janeiro (CEDAE), abastece mais de 40 caminhões pipa, diariamente, para fornecimento à Companhia de Limpeza Urbana do Rio de Janeiro (COMLURB) para fins de lavagem de logradouros públicos. Na Figura 3, observa-se a limpeza da ciclovia da praia de Copacabana e na Figura 4 a lavagem do estacionamento da Praça do Ó, na Barra da Tijuca, após evento de feira livre.

Ainda no Rio de Janeiro, Araujo et al. (2016) afirmam que a ETE Alegria, também operada pela CEDAE, forneceu água de reúso a partir do efluente secundário clorado para as obras do Porto Maravilha durante os anos de 2015 e 2016. $\mathrm{Na}$ fotografia da Figura 5 observa-se 0 abastecimento do caminhão nas instalações da ETE Alegria. Na Cidade de Vitória, no Espírito Santo, também há o abastecimento de caminhões 
pipa a partir do efluente secundário desinfetado por radiação UV da ETE Mulembá, operada pela Companhia Espírito Santense de Saneamento

Figura 3: Limpeza da ciclovia da praia de Copacabana no Rio de Janeiro, com água de reúso

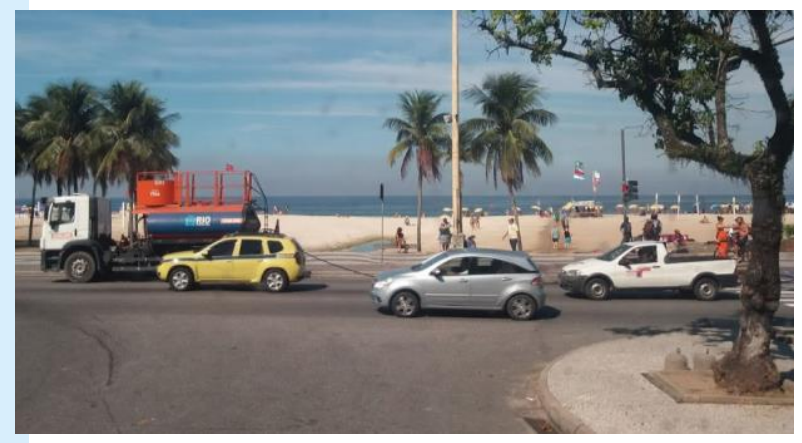

Fonte: Acervo próprio (Ana Silvia Santos).
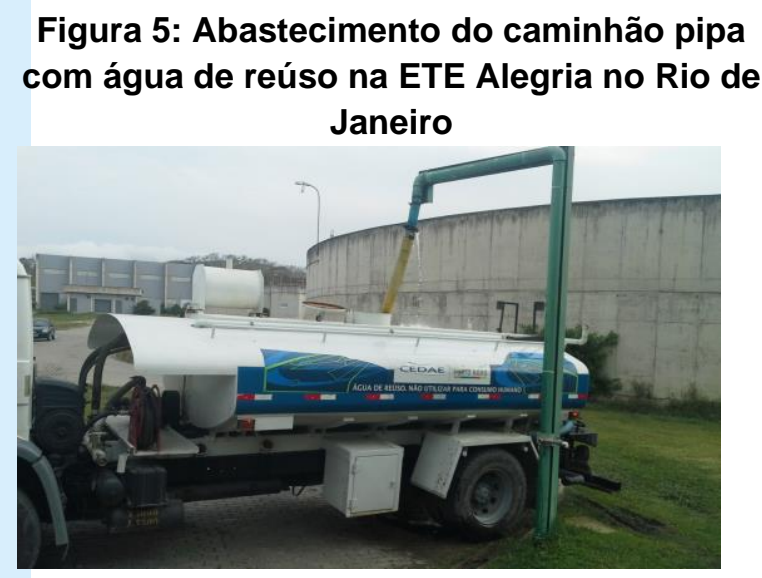

Fonte: Acervo próprio (Ana Silvia Santos).

Outra aplicação comum da água de reúso nos ambientes urbanos no Brasil ocorre em sistemas descentralizados, como edifícios comerciais, residenciais, restaurantes e centros comerciais. Em geral, esses usos são destinados à irrigação de jardins, lavagem de pátios e descarga de bacias sanitários, a partir das águas cinza (Figuras 7, 8 e 9).

Outros exemplos no país poderiam ser aqui destacados, principalmente nas grandes cidades, já que são conhecidas outras iniciativas, como por exemplo a da COMPESA que abastece caminhões da própria companhia de hidrovácuo e jato para serviços operacionais de manutenção e desobstrução da rede de esgotamento sanitário (COMPESA, 2016).

\subsection{AGRÍCOLA}

Como a nível global, o maior consumo de água no Brasil é proveniente da prática de irrigação, que representa quase $50 \%$ das
(CESAN), para limpeza de praças e logradouros públicos do município (Figura 6).

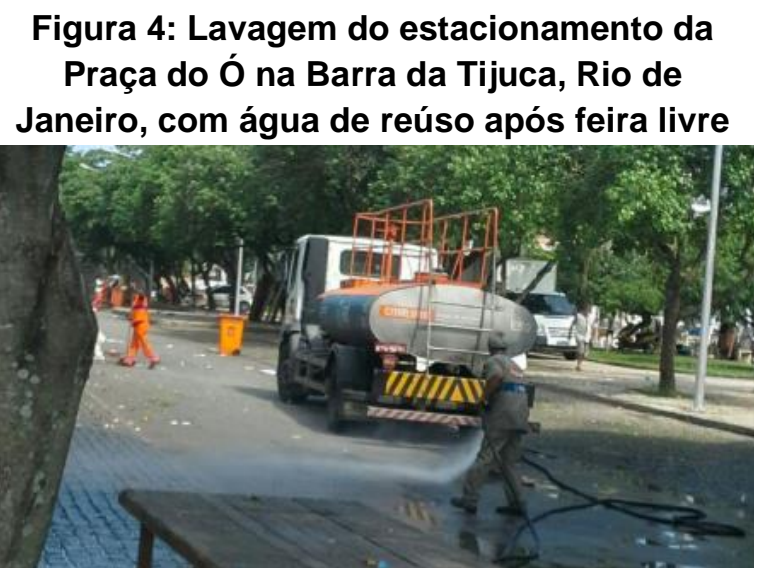

Fonte: Acervo próprio (Ana Silvia Santos).

\section{Figura 6: Abastecimento do caminhão pipa com água de reúso na ETE Mulembá em Vitória/ES}

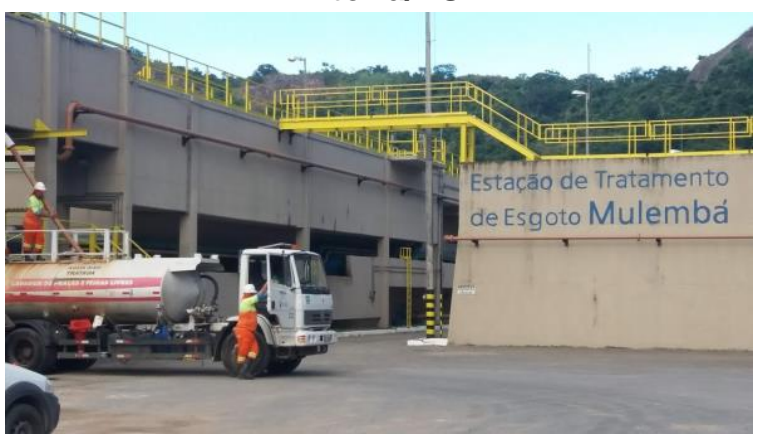

Fonte: Acervo próprio (Ana Silvia Santos).

retiradas de água (ANA, 2020b). Trata-se de uma prática agrícola que utiliza um conjunto de equipamentos e técnicas para suprir a deficiência total ou parcial de água para as plantas. Em geral, a quantidade requerida depende da época do ano, da cultura a ser irrigada, das características do solo e do clima, além do equipamento de irrigação.

De acordo com ANA (2017), a prática de irrigação aumenta o uso da água e isso é um fator negativo para $o$ meio ambiente e para a sustentabilidade dos recursos hídricos; entretanto, de maneira positiva, aumenta a produtividade, reduz os custos unitários, atenua riscos climáticos, otimiza a relação insumos $x$ equipamentos, aumenta a estabilidade e oferta de alimentos, e aumenta a segurança alimentar. De forma a minimizar o impacto do fator negativo e manter os benefícios, a água de reúso surge como fonte alternativa para o favorecimento da prática de irrigação. 
Figura 7: Condomínio residencial da Av. Paulista em São Paulo

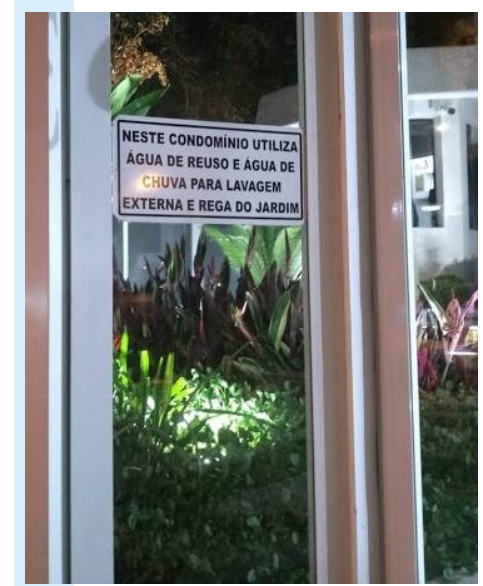

Fonte: Acervo próprio (Ana Silvia Santos).
Figura 8: Banheiro do Shopping Continental em São Paulo

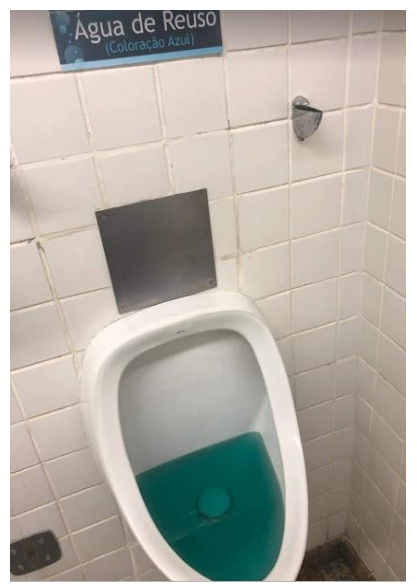

Fonte: Acervo próprio (Cedido por Alfredo Akira Ohnuma Jr.).
Figura 9: Banheiro do restaurante Outback no Shopping Leblon no Rio de Janeiro

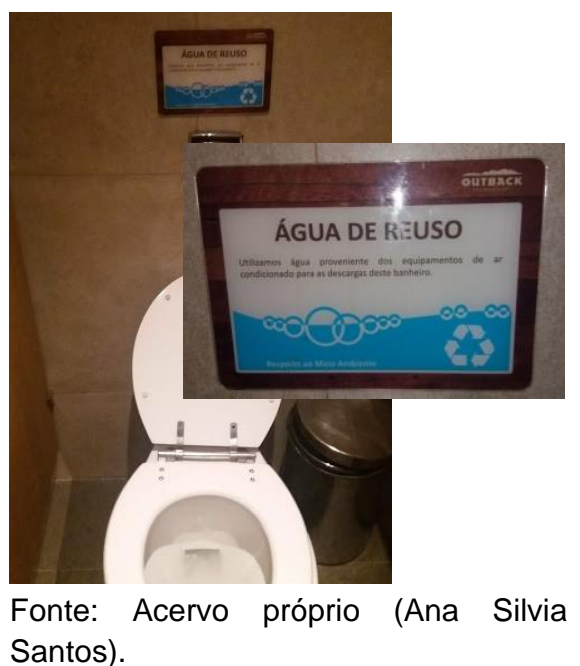

Já são conhecidas experiências de reúso agrícola no país, principalmente em regiões com extrema escassez hídrica, como é o caso do Semiárido e da região Nordeste como um todo. No entanto, esses projetos, de maneira geral, também não são publicados, dificultando a troca de experiências para o aprimoramento da técnica.

O Instituto Nacional do Semiárido (INSA) vem desenvolvendo pesquisas e parcerias com 0 intuito de fomentar a prática de reúso na região. Uma das ações de experiência bem-sucedida é a

\section{Figura 10: Unidade familiar rural para produção de água de reúso para fins de irrigação (Cabuti, PB)}

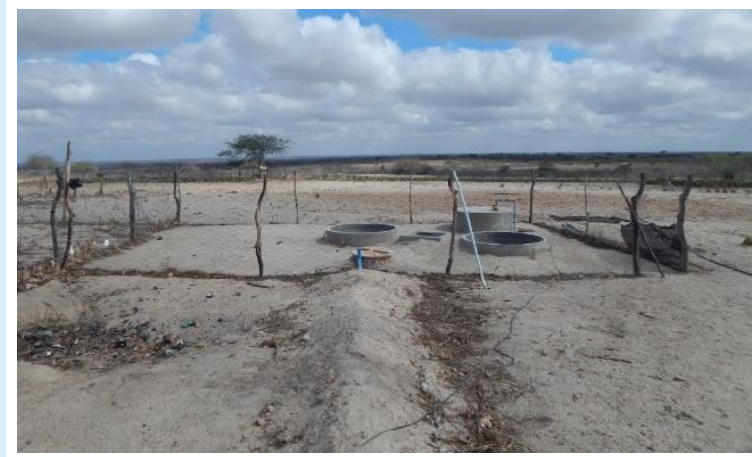

Fonte: Acervo próprio (Cedido por Salomão Medeiros).

Nas regiões com baixa disponibilidade hídrica, o reúso de água se apresenta como uma condição única de irrigação, tanto em sistemas abordagem do reúso descentralizado com tecnologias simplificadas tanto de tratamento como para reúso em unidades familiares rurais. As fotografias das Figuras 10 e 11 destacam a experiência realizada em Cubati, na Paraíba, para irrigação de cajueiros. Padrões compatíveis com aqueles recomendados pela Organização Mundial de Saúde (SANTOS et al., 2020), mais flexíveis que os estabelecidos pelo Interáguas, são alcançáveis com mais facilidade nessas ações.

\section{Figura 11: Irrigação de cajueiros, com} água de reúso, por gotejamento (Cabuti,

PB)

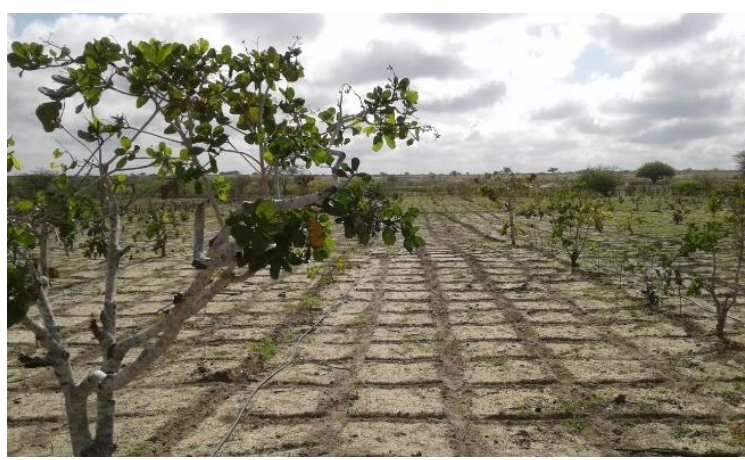

Fonte: Acervo próprio (Cedido por Salomão Medeiros).

descentralizados como centralizados; muitas vezes utiliza-se efluentes de baixa qualidade ou até mesmo brutos. Destaca-se assim, que um 
planejamento adequado nesse sentido, com a otimização das ETEs do entorno para a produção de água reúso com a qualidade compatível (em casos de sistemas centralizados), pode alavancar, de maneira segura, o desenvolvimento socioeconômico dessas regiões.

Como observado na Tabela 1, os padrões de reúso indicados pelo Interáguas são bastante restritivos, principalmente para irrigação de culturas alimentícias que se desenvolvem rente ao solo sem processamento prévio. No caso das demais culturas, os padrões embora exigentes, são um pouco mais flexíveis, considerando a densidade de Coliformes Termotolerantes inferior a $10^{3} \mathrm{NMP} / 100 \mathrm{~mL}$. Em geral, efluentes secundários não alcançam essa qualidade, requerendo, portanto, uma desinfecção. Chamase a atenção para a tecnologia de desinfecção mais comum no Brasil, realizada com cloração, que pode trazer danos tanto à cultura como ao meio ambiente. Nesse contexto, destaca-se ainda a possibilidade de suprir não somente a demanda de água para as culturas, como também a de nutrientes. A prática, nesse caso, é conhecida como fertirrigação e deve ser também considerada nas etapas de planejamento.

Como forma de subsidiar o planejamento das ações de reúso para irrigação em todas as Regiões Hidrográficas do Brasil, Lima et al. (2020) realizaram estudo que apresenta resultados importantes para os tomadores de decisão. De maneira geral, os autores concluíram que Regiões Hidrográficas parcialmente ou integralmente inseridas na Região do Semiárido (região mais afetada pela seca no Brasil), como Atlântico Leste, São Francisco, Nordeste Oriental, Nordeste Ocidental e Parnaíba, apresentam capacidade parcialmente instalada de atendimento a aproximadamente $2,0 \%, 4,5 \%$, $10,0 \%, 1,0 \%$ e $2,5 \%$ da demanda para irrigação, respectivamente. Os baixos índices de atendimento a coleta e tratamento de esgotos são responsáveis pelos valores também mais baixos de potencial. Dessa forma, o planejamento das ações de reúso nessas regiões, ainda deve levar em consideração o alcance da universalização dos serviços, inclusive para a produção de maior vazão de água de reúso.

\subsection{INDUSTRIAL}

O reúso das águas residuárias produzidas nas indústrias, em geral, tem um caráter descentralizado. Aqui é importante se diferenciar as águas residuárias produzidas na fabricação dos produtos, que apresentam características específicas aos processos que as geram, das águas residuárias dos setores administrativo, restaurantes e vestiários, que apresentam características semelhantes ao esgoto doméstico.

Muitas vezes, o reúso de água interno à indústria pode ser praticado a partir destas fontes de água em duas situações específicas: 1) no próprio processo industrial ou em equipamentos como torres de resfriamento e caldeiras; 2) na lavagem de veículos e/ou de equipamentos, lavagem de pátios e estacionamentos, irrigação de jardins, descarga de bacias sanitárias, combate a incêndio.

No primeiro caso, independentemente da fonte da água de reúso, suas características físico-químicas e biológicas deverão ser compatíveis com o processo produtivo. Em outras palavras, a água de reúso não pode interferir na qualidade do produto da indústria, o que exige uma padronização específica para cada processo produtivo. Por esse motivo, o arcabouço regulatório do reúso de água na maioria dos países não contempla o reúso industrial, tendo em consideração as inúmeras especificidades de cada indústria. Porém, em se tratando dos usos não potáveis descritos no segundo caso do parágrafo anterior, a qualidade da água de reúso poderá seguir as orientações e critérios estipulados pela NBR 16.783/2019 (ABNT, 2019b).

Por outro lado, o reúso industrial considerando água produzida em ETEs centralizadas, apesar de menos comum, tem um grande potencial no país. $\mathrm{O}$ maior empreendimento desse tipo na América do Sul encontra-se instalado no estado de São Paulo. Trata-se do Projeto Aquapolo, que utiliza efluente secundário produzido na ETE ABC, operada pela Companhia de Saneamento Básico do Estado de São Paulo (SABESP), para produção de água de reúso com o objetivo de abastecimento do Polo Petroquímico do $A B C$ paulista. No Aquapolo, o efluente da ETE $A B C$ passa por um processo composto por reator biológico de membranas de ultrafiltração e osmose inversa, apresentando um efluente final de qualidade compatível com os usos definidos em contrato (Figura 12).

Nesse tipo de projeto, uma questão estratégica a se tratar é a distância entre o produtor da água de reúso (ETE do sistema centralizado) e o consumidor (parque industrial), além da forma de transporte. No caso do Projeto Aquapolo, a adutora da água de reúso tem 
comprimento de $17 \mathrm{~km}$, com capacidade para transportar $650 \mathrm{~L} / \mathrm{s}$, e representou um custo bastante elevado em relação ao empreendimento completo. Outro aspecto relevante se refere ao consumo de energia na produção da água de reúso, que impacta significativamente os custos de operação e manutenção da EPAR. O consumo de energia depende diretamente do tipo de tecnologia empregado na produção da água de reúso, que, regra geral, aumenta com o nível de qualidade pretendido.

Destaca-se ainda, que o setor industrial, por motivos financeiros e/ou de condução de práticas sustentáveis com objetivo de valorização da imagem, pratica a conservação e o uso racional de água a partir de circuitos internos de torres de resfriamento, reutilização de águas de lavagem e outros. Em função das peculiaridades do Brasil e da sua extensa dimensão territorial, é certo que outros projetos, além do Aquapolo, praticam ações de reutilização ou reciclagem de água, assim como no caso de algumas indústrias do Polo Camaçari no estado da Bahia.

O tipo de indústria influencia substancialmente na sua conduta em termos de reúso. Em geral, não se aconselha o reúso de água em indústrias do setor alimentício. Inclusive, as diretrizes do Programa Interáguas limitam esse uso (INTERÁGUAS, 2017).

Figura 12: Desenho esquemático do fluxograma do Projeto Aquapolo

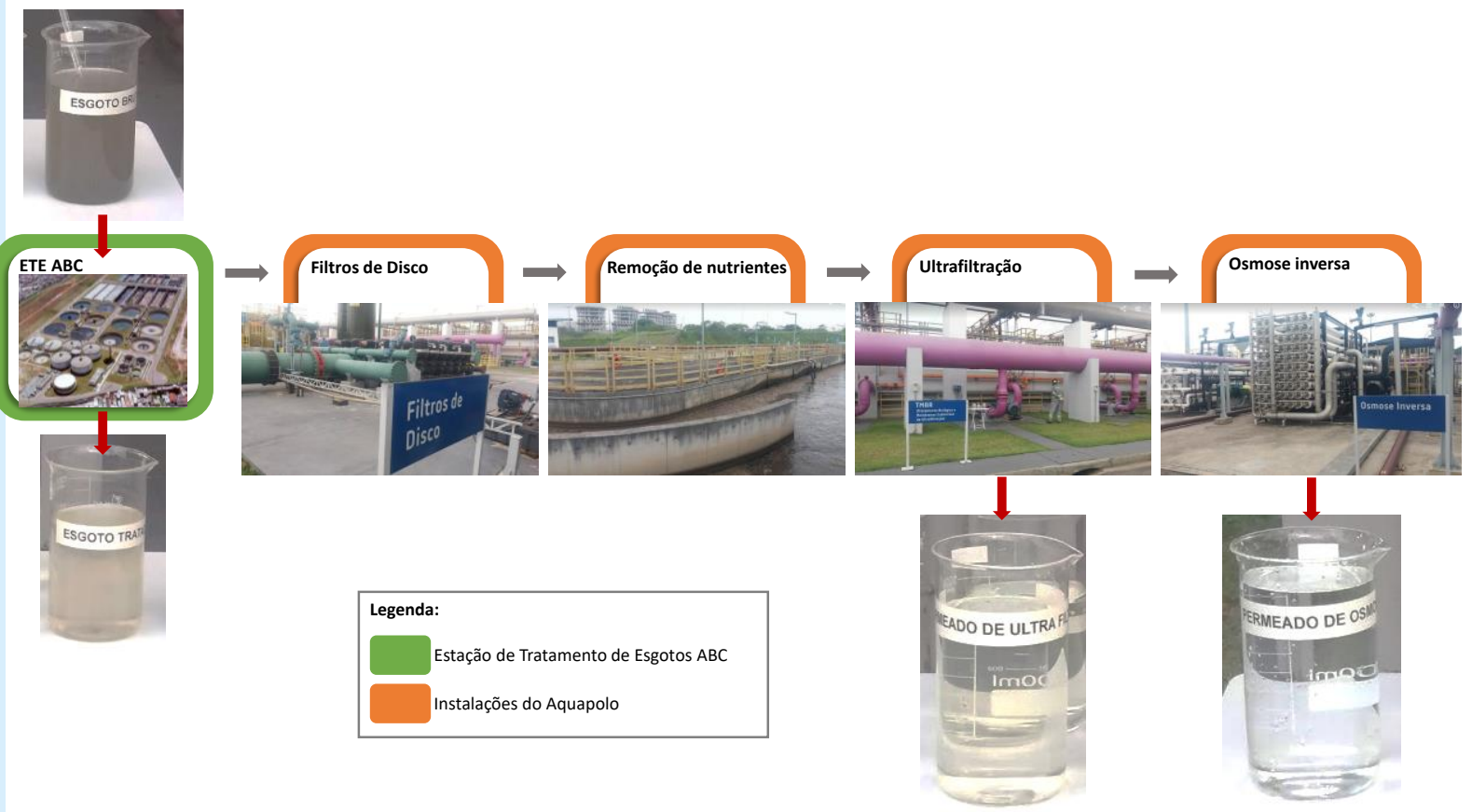

Fonte: Elaborado pelos autores. Fotografias de acervo próprio (Ana Silvia Santos), exceto a da ETE ABC (InstitutoTratabrasil).

\section{CONSIDERAÇÕES FINAIS}

A experiência recente vem demonstrando que o Brasil possui um nível de desenvolvimento socioeconômico e tecnológico que justifica amplamente a implementação, com sucesso, de projetos de reúso de água em diferentes modalidades. Vários projetos de reúso de água estão sendo implantados no país em um ambiente desorganizado do ponto de vista institucional, em que a governança se faz ausente nos níveis federal, estadual e municipal.
Com o objetivo de propor uma metodologia estruturada para diagnóstico do potencial de reúso de água numa matriz hídrica regional, apresentam-se nesta Nota Técnica os principais conceitos e terminologia à guisa de consolidação. Apresenta, ainda, uma síntese do arcabouço regulador nacional assim como algumas experiências em curso no país.

Em relação aos instrumentos regulatórios referentes ao reúso de água no Brasil, tanto mandatórios quanto não mandatórios, é evidente que todos são relativamente recentes, com no 
máximo 20 anos de existência. Apesar de já terem sido realizados grandes avanços na temática, ainda é necessário um fomento maior para a concretização de uma legislação a nível federal, contemplando diretrizes, critérios e parâmetros para esta prática. Faz-se notar que esta futura legislação deve ser atrelada a alguns fatores: o planejamento adequado, 0 licenciamento dos produtores, distribuidores e consumidores, a avaliação de risco para os envolvidos, a fiscalização do desempenho dos empreendimentos, entre outros.

\section{AGRADECIMENTOS}

Os autores agradecem o Professor Alfredo Akira Ohnuma Jr. e o Pesquisador Salomão Medeiros pela disponibilização de fotografias que ilustram algumas das práticas de reúso de água abordadas no presente texto.

\section{REFERÊNCIAS}

ABNT. ASSOCIAÇÃO BRASILEIRA DE NORMAS TÉCNICAS. NBR 13969: Tanques sépticos - Unidades de tratamento complementar e disposição final dos efluentes líquidos - Projeto, construção e operação. Rio de Janeiro. 60p. 1997.

ABNT. ASSOCIAÇÃO BRASILEIRA DE NORMAS TÉCNICAS. NBR 16782: Conservação de água em edificações - Requisitos, procedimentos e diretrizes. Rio de Janeiro. 22p. 2019.

ABNT. ASSOCIAÇÃO BRASILEIRA DE NORMAS TÉCNICAS. NBR 16783: Uso de fontes alternativas de água não potável em edificações. Rio de Janeiro. 19p. 2019.

ANA. AGÊNCIA NACIONAL DE ÁGUAS E SANEAMENTO BÁSICO. Atlas irrigação: uso da água na agricultura irrigada. Brasília, DF: ANA, 2017.

ANA. AGÊNCIA NACIONAL DE ÁGUAS E SANEAMENTO BÁSICO. Atlas esgotos: atualização da base de dados de estações de tratamento de esgotos no Brasil. Brasília, DF: ANA, 2020a.

ANA. AGÊNCIA NACIONAL DE ÁGUAS E SANEAMENTO BÁSICO. Conjuntura dos recursos hídricos no Brasil 2020: informe anual. Brasília, DF: ANA, 2020b.

ANGELAKIS, A. N.; ASANO, T.; BAHRI, A.; JIMENEZ, B. E.; TCHOBANOGLOUS G. Water Reuse: From Ancient to Modern Times and the Future. Frontiers Environmental Science, v.6, n.26, 2018.
ARAUJO, B. M.; MANHAES, A. C. D.; SANTOS, A.S.P. Viabilidade Econômica e Análise das Práticas de Reúso dos Efluentes das Estações de Tratamento de Esgoto do Município do Rio de Janeiro - ETE Alegria e ETE Penha. In: XVII Simpósio Luso Brasileiro de Engenharia Ambiental e Sanitária, Florianópolis, 2016. Anais [...], Florianópolis, SC, 2016.

ARAUJO, B. M.; SANTOS, A. S. P.; PAVAN, F. Comparativo econômico entre o custo estimado do reúso de efluente de ETE para fins industriais não potáveis em comparação ao valor da água potável para a região sudeste do Brasil. Exatas \& Engenharias, v. 7, n. 17, 2017.

ARAUJO, B. M.; SANTOS, A. S. P.; SOARES, S. R. A.; MELO, M. C. DE; OHNUMA JUNIOR, A. A. Aspectos econômicos para o reúso na agricultura na Bacia do Rio Paraíba do Sul e comparação com o modelo da gestão de cobrança em Israel. In: III Simpósio de Recursos Hídricos do Rio Paraíba do Sul, Juiz de Fora, MG, 2018. Anais [...], Juiz de Fora, MG, 2018.

BASTOS, R.K.X.; NEVES, J.C.I.; BEVILACQUA, P.D.; SILVA, C.V.; CARVALHO, G. R.M. Avaliação da contaminação de hortaliças irrigadas com esgotos sanitários. In: XXVII Congreso Interamericano Ingenieria Sanitaria y Ambiental, México, 2002. Anais [...], México, 2002.

BASTOS, R. K. X.; KIPERSTOK, A.; CHERNICHARO, C. A. L.; FLORENCIO, L.; MONTEGGIA, L. O.; SPERLING, M.; AISSE, M. M.; BEVILAQUA, P. D.; PIVELI, R. P. Subsídios à regulamentação do reúso de águas no Brasil - Utilização de esgotos sanitários tratados para fins agrícolas, urbanos e piscicultura. Revista DAE, v. 177, n. 122, 2008.

BRASIL. Lei no 14.026, 15 de julho de 2020. Atualiza o marco legal do saneamento básico e altera as Leis $n^{\circ}$ 9.984/2020, no 10.768/2003, no 11.107/2005, nº 11.445/2007, no 12.305/2010, no 13.089/2015, no 13.5029/2017. Diário Oficial da União, Brasília, 15 de julho de 2020.

BRASIL. Resolução CNRH no 54, de 28 de novembro 2005. Estabelece modalidades, diretrizes e critérios para o reúso direito não potável de água, e dá outras providências. Diário Oficial da União, Brasília, v. 3, n. 1, p. 31, 28 nov. 2005a. Seção 1, p. 31-36, 2005.

BRASIL. Resolução CONAMA no 430, de 13 de maio de 2011. Dispõe sobre as condições e padrões de lançamento de efluentes, complementa e altera a Resolução no 357, de 17 de março de 2005, do Conselho Nacional do Meio Ambiente-CONAMA. Diário Oficial da União, Brasília, v. 2, n. 1, p. 43, 13 maio 2011. Seção 1, p. 43-46, 2011. 
COMPESA. COMPANHIA PERNAMBUCANA DE SANEAMENTO. Cidade Saneada adota prática que economiza quase $\mathbf{1 0 0}$ mil litros de água por dia. Disponível em: https://servicos.compesa.com.br/cidadesaneada-adota-pratica-que-economiza-quase-100-millitros-de-agua-por-dia/. Acesso em: 15 de dez. 2020. (2016)

COMPESA. COMPANHIA PERNAMBUCANA DE SANEAMENTO. Reúso para ETEs. Informações Gerais para o PMI de Reúso para ETEs. Disponível em: https://servicos.compesa.com.br/portal-deparcerias/reúso-para-etes/. Acesso em: 15 de dez. 2020. (2020)

HESPANHOL, I. Potencial de reúso de água no Brasil: Aquicultura, Indústria, Municípios, Recarga de Aquíferos. Revista Brasileira de Recrusos Hídricos, v. 7, n. $4,2002$.

IICA. INSTITUTO INTERAMERICANO DE COPERACIÓN PARA LA AGRICULTURA. Estudo revela potencial de reúso de esgoto tratado na Bahia. Disponível em:

https://www.iica.int/es/prensa/noticias/estudo-revelapotencial-de-reúso-de-esgoto-tratado-na-ba. Acesso em: 20 de nov. 2020.

\section{INTERÁGUAS - PROGRAMA DE}

DESENVOLVIMENTO DO SETOR ÁGUAS.

Elaboração de proposta de plano de ações para instituir uma política de reúso de efluente sanitário tratado no Brasil. Produto III - Critérios de qualidade de água. Brasília. 2017.

LIMA, M.; ARAUJO, B. M.; SOARES, S. R. A.; SANTOS, A. S. P.; VIEIRA, J. M. P.; Water reuse potential for irrigation in Brazilian hydrographic regions. Water Supply, 2020.

MARIN, P.; TAL, S.; YERES, J.; RINGSKOG, K. Water Management in Israel: Key Innovations and Lessons Learned for Water Scarce Countries. World Bank, Washington, DC. 2017.

MELO, M. C.; SANTOS, A. S. P.; VIEIRA, J. M. P. A nova centralidade da água e do saneamento pósCOVID-19. Revista Augustus, v.25, n. 51, p. 294-315, 2020a.
MELO, M. C.; PEREIRA SANTOS, A. S.; PINHEIRO SANTOS, N. A.; MAGALHÃES DE ARAÚJO, B.; ROSA SILVA DE OLIVEIRA, J.; RIBEIRO CAMPOS, A.

Evaluation of potential use of domestic treated effluents or irrigation in areas subject to conflicts over water use in Paracatu River Basin. Caminhos da Geografia (UFU. Online), v. 21, p. 52-63, 2020 b.

OMS. ORGANIZAÇÃO MUNDIAL DE SAÚDE. Guidelines for the safe use of wastewater, excreta and greywater. Volume 2: Wastewater use in agriculture. Geneva: World Health Organization. 2006.

OMS. ORGANIZAÇÃO MUNDIAL DE SAÚDE. Potable reuse: Guidance for producing safe drinking-water. Geneva: World Health Organization. 2017.

\section{SANASA. SOCIEDADE DE ABASTECIMENTO DE} ÁGUA E SANEAMENTO. Página principal. Disponível em: http://www.sanasa.com.br/inicio/default.aspx. Acesso em: 14 de dez. 2020.

SANTOS, A. S. P.; GONÇALVES, R. F.; MELO, M. C.; LIMA, M. A. M.; ARAUJO, B. M. Uma análise crítica sobre os padrões de qualidade de água de uso e de reúso no Brasil. Revista Sustinere, v. 8, n. 2, p. 437462, 2020.

SANTOS, A. S. P.; VIEIRA, J. M. P. reúso de água para o desenvolvimento sustentável: Aspectos de regulamentação no Brasil e em Portugal. Revista Eletrônica de Gestão e Tecnologias Ambientais, v. 8, p. 50-68, 2020.

SILVA JUNIOR, L. C. S.; ARAUJO, B. M.; SANTOS, A. S. P; OBRACZKA, M.; BOTTREL, S.E.C. Panorama do reúso de efluentes nas estações de tratamento de esgoto da região Sudeste. In: $30^{\circ}$ Congresso Brasileiro de Engenharia Sanitária e Ambiental, Natal, RN, 2019. Anais [...], Natal, RN, 2019.

\section{WATER EUROPE. A water smart society for a} successful post COVID19 recovery plan. Bruxelas: WE, 2020. Disponível em: https://watereurope.eu/wpcontent/uploads/2020/04/A-Water-Smart-Society-for-apost-covid19-recovery-plan.pdf. Acesso em: 9 dez. de 2020. 